\title{
In situ observation of shrinking and swelling of normal and compression Chinese fir wood at the tissue, cell and cell wall level
}

\author{
Tianyi Zhan ${ }^{1} \cdot$ Jianxiong Lyu ${ }^{1,2} \cdot$ Michaela Eder $^{3}$
}

Received: 11 December 2020 / Accepted: 19 July 2021 / Published online: 7 August 2021

(c) The Author(s) 2021

\begin{abstract}
The shrinking and swelling of wood due to moisture changes are intrinsic material properties that control and limit the use of wood in many applications. Herein, hygroscopic deformations of normal and compression wood of Chinese fir (Cunninghamia lanceolata [Lamb.] Hook.) were measured during desorption and absorption processes. The dimensional changes were observed in situ by an environmental scanning electron microscope and analyzed at different hierarchical levels (tissue, cell and cell wall). The relationship between moisture variation and hygroscopic deformation was measured. During initial desorption periods from 95 to 90 or $75 \% \mathrm{RH}$, an expansion of the lumen and a shrinkage of the cell wall were observed, revealing a non-uniform and directional deformation of single wood cells. The variation of shrinking or swelling at different hierarchical levels (tissue, cell and cell wall) indicates that the hygroscopic middle lamella plays a role in the deformation at the tissue level. Higher microfibril angles and helical cavities on the cell wall in compression wood correlate with a lower shrinking/swelling ratio. Normal wood showed a more pronounced swelling hysteresis than compression wood, while the sorption hysteresis was almost the same for both wood types. This finding is helpful to elucidate effects of micro- and ultrastructure on sorption. The present findings suggest that the sophisticated system of wood has the abilities to adjust the hygroscopic deformations by fine-tuning its hierarchical structures.
\end{abstract}

Jianxiong Lyu

jianxiong@caf.ac.cn

$\bowtie$ Michaela Eder

michaela.eder@mpikg.mpg.de

1 College of Materials Science and Engineering, Nanjing Forestry University, 210037 Nanjing, People's Republic of China

2 Research Institute of Wood Industry of Chinese Academy of Forestry, 100091 Beijing, People's Republic of China

3 Department of Biomaterials, Max-Planck-Institute of Colloids and Interfaces, Am Mühlenberg 1, 14476 Potsdam, Germany 


\section{Introduction}

In the living tree, wood is in its fully hydrated state. After harvest, it undergoes drying and the intrinsically hygroscopic material is commonly subjected to variations in the environmental conditions, such as relative humidity (RH) during its use. Fluctuations in RH lead to changing wood moisture contents (MCs). As wood absorbs water, it swells and with desorption it shrinks (Patera et al. 2013). Severe moistureinduced deformation frequently causes problems in applications such as warping or distortion.

The origin of shrinking and swelling is attributed to the water sorption in the cell wall. When water absorbs or desorbs within the cell wall, the cell wall volume increases or decreases. The dimensional change of cell walls is directional and depends on the orientation of the cellulose fibrils in the cell walls since their lengths do not undergo large changes upon water uptake. At the macroscale, the arrangement of the cells, the microfibril angle (MFA) and the interaction between earlywood and latewood influence the anisotropic hygrodeformations (Garcia et al. 2020; Patera et al. 2018; Siau 2012). Dimensional changes of 6-12\% in the tangential direction, $3-6 \%$ in the radial direction and $0.1-0.3 \%$ in the longitudinal direction are reported for normal wood (Skaar 2012). However, the rate of shrinking or swelling depends on the length scale, and it has been shown on micropillars of the S2 layer that cell wall swelling exceeds the swelling of the cell and tissue (Chen et al. 2020; Rafsanjani et al. 2014). One reason is that restraining effects from the other cell wall layers with different cellulose orientations are missing (Skaar 2012). At the tissue scale, the hygrodeformation is affected by the constraining stress transfer between cells and the compositions and microstructure of cell wall layers (Joffre et al. 2016; Lanvermann et al. 2014). Honeycomb cellular solids with homogenous cell walls deform isotropically, while honeycombs with a layered cell wall structure display anisotropic swelling behavior (Arzola-Villegas et al. 2019; Rafsanjani et al. 2013). In the secondary cell wall, cellulose microfibrils are wound around the longitudinal axis of the fiber with a certain angle and surrounded by the amorphous hemicellulose and lignin. The helical structure of the main layer of the cell wall implies that the fiber will twist if the MC changes (Burgert et al. 2005; Plaza et al. 2013). However, in a tissue such a twist of a single fiber is constrained by adjacent fibers.

Within the S2 nanostructure, cellulose and amorphous hemicellulose and lignin exhibit diverse hygrodeformations. The cellulose crystalline lattice is deformed with changes in wood MC (Arzola-Villegas et al. 2019). Abe and Yamamoto (2005; 2006) pointed out that the lateral expansion of crystalline cellulose is induced by the shrinking stresses of hemicellulose and lignin, while Zabler et al. (2010) believed that the expansion is created by the condensation and evaporation of water on the hydrophilic surface of the microfibrils.

Moisture-induced dimensional change of wood has been studied experimentally (Chen et al. 2020; Derome et al. 2011; Joffre et al. 2016; Ma et al. 2010; Perré 2005; Sakagami et al. 2007) and by molecular dynamics simulations (Chen et al. 2018; Derome et al. 2018; Kulasinski et al. 2015a, 2015b). In experiments, dimensional changes (especially in radial and tangential directions) and resulting stresses are 
determined from the macroscale to the cell wall scale. Testing materials used in most of the reported studies are gymnosperms, because of the relatively simple structure.

Plantation Chinese fir (Cunninghamia lanceolata [Lamb.] Hook.), as a valuable domestic Chinese species, is widely cultivated in the southern area of China. Related investigations of its physical and mechanical properties include Bao et al. (2001), Jiang et al. (2012), Peng et al. (2019a), Wang and Rennolls (2005), Wang et al. (2006), Yin et al. (2010, 2015) and Zhan et al. (2019). Similarly to other gymnosperms, Chinese fir responds to stimuli such as stem inclinations caused by slopes, winds or other external forces, with compression wood formation on the lower side of a branch or an inclined stem (Timell 1986). Characteristics of compression wood are thicker walled and roundish cells, a higher lignin content and a higher MFA. It is widely accepted that wood with a higher MFA shows reduced swelling in its transverse direction upon humidity changes (Burgert et al. 2007; Joffre et al. 2014; Perré and Huber 2007).

Moisture-induced deformation of wood is closely related to the drying quality (Keey et al. 2000; Redman et al. 2016), but it also has the potential for fabrication of self-shaping composites or otherwise active materials (Eder et al. 2020; Grönquist et al. 2019; Wood et al. 2018). Toward a more efficient and sustainable material use, a deep understanding of the swelling properties is essential. In this study, the shrinking and swelling properties of Chinese fir were studied in situ by an environmental scanning electron microscope (ESEM), making use of the high resolution provided by scanning electron microscopy. Swelling was analyzed at the tissue, cell and cell wall scale, and different locations within a growth ring were compared. The influences of the micro- and nanostructure on the dimensional deformation were discussed to explore origins of shrinking and swelling variations between normal and compression wood of Chinese fir.

\section{Materials and methods}

\section{Sampling}

Normal and compression wood of Chinese fir were selected from plantation trees grown in Zhejiang, China. Samples were obtained from air-dried logs. Samples with dimensions of $6 \times 0.8 \times 0.5 \mathrm{~mm}^{3}$ (radial $\times$ tangential $\times$ longitudinal) were cut for the shrinking/swelling tests. Within the cross section of the samples, a region containing the whole transition from early- to latewood within the 11th annual ring was present (Fig. 1). The surface of the samples was prepared by removing 1-2- $\mu \mathrm{m}$ thin slices with a cryomicrotome HM 560 (Microm, Germany). Three normal wood and three compression wood samples were prepared. All the samples were soaked in distilled water for 7 days to achieve a water-saturated state. In addition, 20- $\mu \mathrm{m}$-thick sections (cross, radial and tangential) and 150- $\mu$ m-thick tangential sections were prepared for anatomical characterization and MFA measurement. After MFA measurement, the sections were cut into chips $\left(1 \times 0.8 \times 0.5 \mathrm{~mm}^{3}\right.$, radial $\times$ tangential $\times$ longitudinal $)$ for desorption and absorption isothermals. 
Normal wood
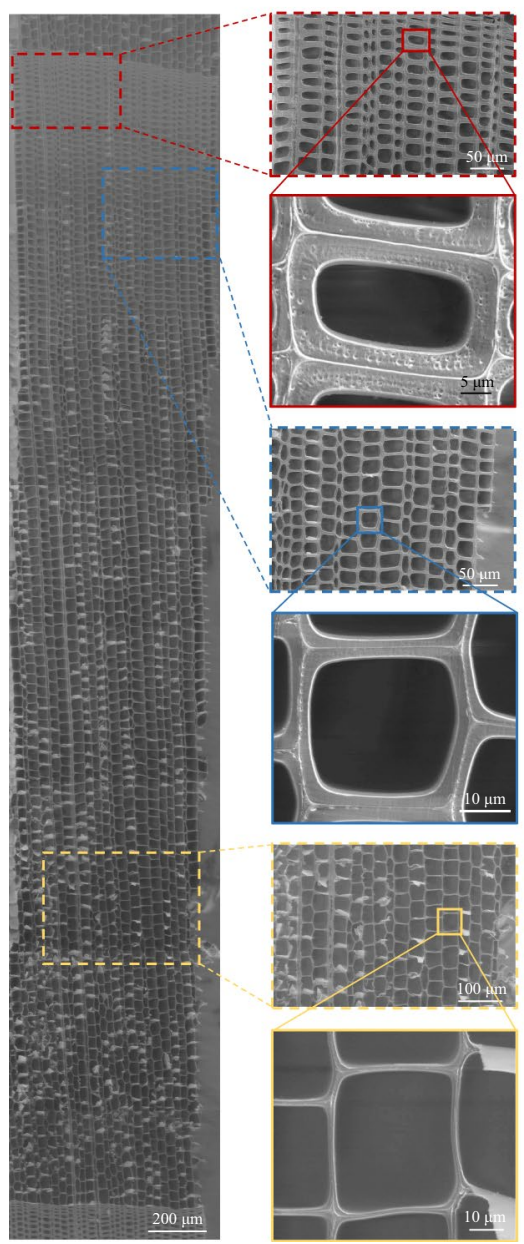

Compression wood
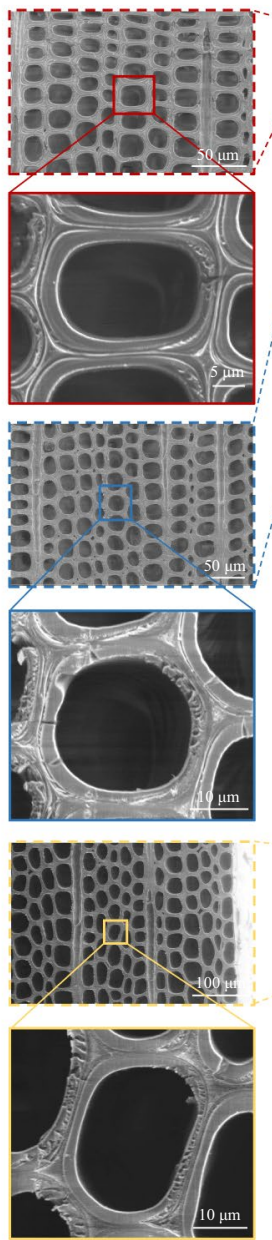

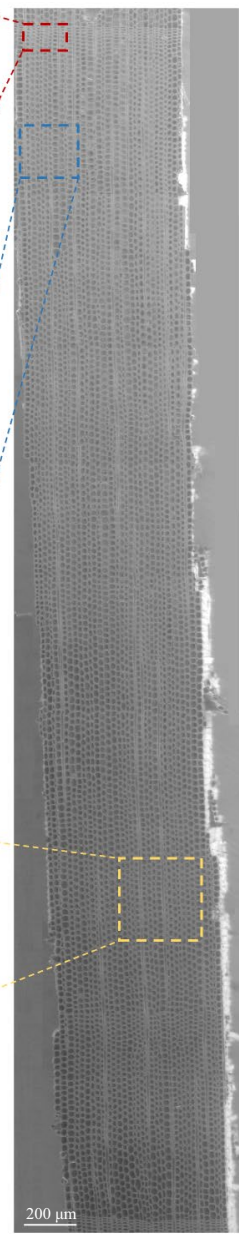

Fig. 1 Typical sampling locations and cell features of the normal and compression Chinese fir wood

\section{Microfibril angle measurement}

The MFAs were determined by a wide-angle X-ray scattering experiment in a Bruker nanostar device. The $150-\mu \mathrm{m}$-thick tangential sections were exposed to $\mathrm{Cu} \mathrm{K} \alpha \mathrm{X}$-ray radiation with a wavelength of 1.54 Angstöm. The distance between the sample and the Vantec 2000 detector was $\sim 5 \mathrm{~mm}$. The recorded 2D diffraction pattern was integrated, and the cellulose MFA was evaluated by the azimuthally scattering intensity distribution of the cellulose 200 reflection (Lichtenegger et al. 1997). Three replicates for each location were performed. 


\section{Anatomical characterization}

The microscopic structure of the samples was studied with a digital microscope (Keyence VHX-S550E, Keyence Company, Japan) equipped with a universal objective (VH-Z100UR) and operated in the transmission mode.

\section{In situ shrinking and swelling}

\section{Desorption and absorption experiment}

The moisture desorption and absorption experiments were carried out in an ESEM (FEI Quanta FEG 600, FEI Company, USA). Temperature and vapor pressure in the sample chamber were controlled to provide different RHs. The sample in the chamber was exposed to a conditioning process. Firstly, the ESEM was pumped down to $931 \mathrm{~Pa}(100 \% \mathrm{RH})$ at a temperature of $6{ }^{\circ} \mathrm{C}$. After 24 -h conditioning, vapor pressure was reduced to $878 \mathrm{~Pa}(95 \% \mathrm{RH})$ for $12 \mathrm{~h}$. The desorption and absorption experiments were carried out by reducing and raising the vapor pressure progressively at $6{ }^{\circ} \mathrm{C}$, corresponding to different RHs. At each RH level, the sample was permitted to reach a new equilibrium $\mathrm{MC}$ within $12 \mathrm{~h}$. Figure 2 illustrates the temperature, vapor pressure and corresponding RH conditions at each humidity step.

\section{Measurement of dimensional changes}

In each normal and compression wood sample, areas from latewood, transition wood and earlywood with high surface qualities were selected and monitored during the desorption and absorption experiments. Typical sampling locations and cell features are shown in Fig. 1. At the end of each desorption or absorption step, the traced

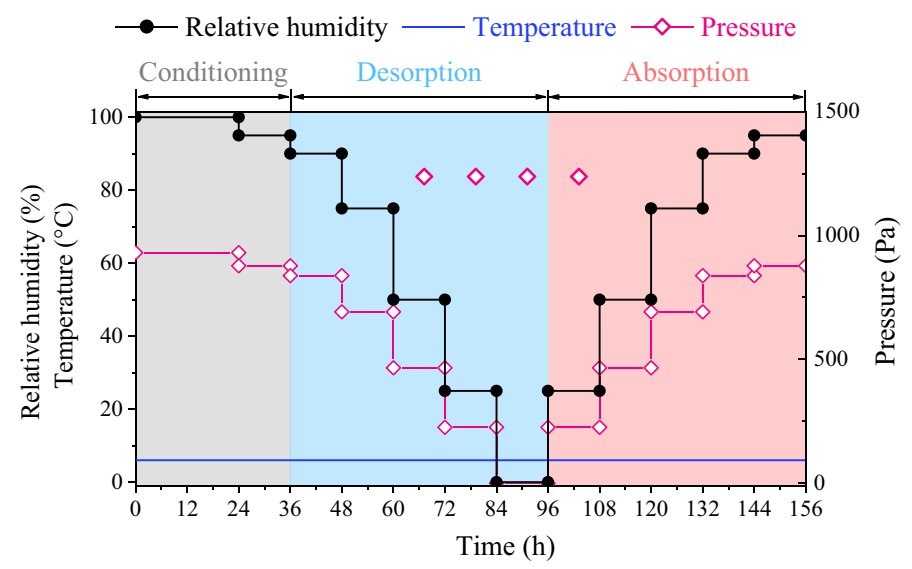

Fig. 2 Temperature, pressure and humidity conditions at each step for conditioning, desorption and absorption runs 
cells were scanned, and their cross-sectional areas were measured by ImageJ software (https://imagej.nih.gov/ij/).

For the traced cells, the changes in cross-sectional areas were calculated as follows:

$$
\begin{gathered}
R A_{\text {cell }}=\frac{S_{\text {cell }}^{\mathrm{i}}}{S_{\text {cell }}^{0}} \\
R A_{\text {lumen }}=\frac{S_{\text {lumen }}^{\mathrm{i}}}{S_{\text {lumen }}^{0}} \\
R A_{\text {cell wall }}=\frac{S_{\text {cell wall }}^{\mathrm{i}}}{S_{\text {cell wall }}^{0}}
\end{gathered}
$$

where $R A$ and $S$ are the relative area and real area $\left(\mu \mathrm{m}^{2}\right)$, respectively. The subscripts "cell," "lumen" and "cell wall" designate the corresponding data for cell, lumen and cell wall. The superscript " 0 " designates the corresponding data at the end of the conditioning step (i.e., the beginning of the desorption step). The superscript "i" designates the corresponding data at the end of every step during the desorption or absorption. The illustration of determination of cell wall and lumen areas is shown in Fig. 3a. When measuring the areas of cells and cell walls $\left(S_{\text {cell }}\right.$ and $\left.S_{\text {cell wall }}\right)$, the inner or outer boundaries of cells were traced manually. The areas of cells were measured including S1, S2 and S3 layers, and the middle lamella was excluded. In addition, $R A$ of tissue $\left(R A_{\text {tissue }}\right)$ at different locations was also measured:

$$
R A_{\text {tissue }}=\frac{S_{\text {tissue }}^{\mathrm{i}}}{S_{\text {tissue }}^{0}}
$$
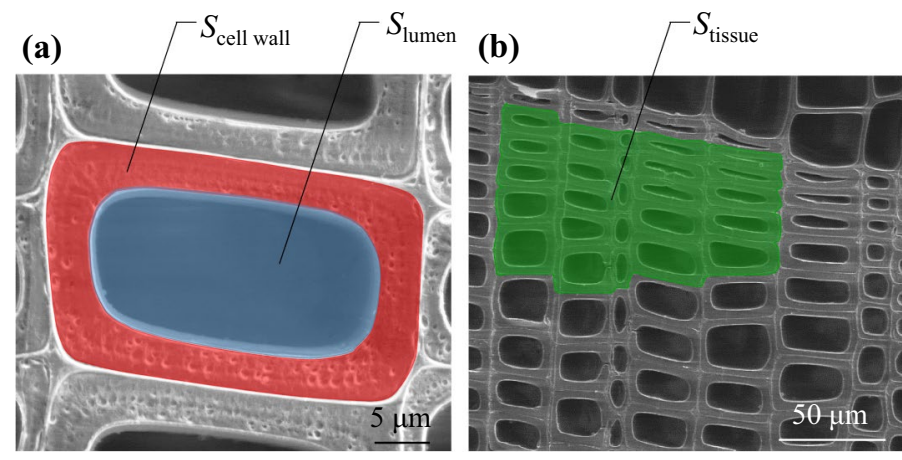

Fig. 3 Illustration of the area determination in single cell (a) and tissue (b) (for single cell, $\left.S_{\text {cell }}=S_{\text {cell wall }}+S_{\text {lumen }}\right)$ 
The tissue was defined by $5 \times 5$ cells in normal latewood and $7 \times 7$ cells in the other locations. The middle lamellae of the outer boundaries were excluded. A typical illustration of a tissue area is displayed in Fig. 3b. No ray cells were included in the measured tissue. The area of each cell or tissue $\left(S_{\text {cell }}, S_{\text {lumen }}, S_{\text {cell wall }}\right.$ or $\left.S_{\text {tissue }}\right)$ was calculated three times, and the average value was obtained to minimize the artificial error. In total, nine single cells and three tissues in each specific sampling location (normal or compression wood, and latewood, transition wood or earlywood) were measured.

\section{Desorption and absorption isothermals}

Desorption and absorption isothermal experiments were conducted on ca. $30 \mathrm{mg}$ water-saturated wood chips by means of a dynamic vapor sorption apparatus (DVS Advantage 2, Surface Measurement Systems Ltd., UK). The temperature was set at $25{ }^{\circ} \mathrm{C}$. The preprogrammed sequence of $\mathrm{RH}$ was identical to the shrinking and swelling experiment $(95 \rightarrow 90 \rightarrow 75 \rightarrow 50 \rightarrow 25 \rightarrow 0 \rightarrow 25 \rightarrow 50 \rightarrow 75 \rightarrow 90 \rightarrow 95 \%)$ in the section Desorption and absorption experiment. At each RH level, the equilibration time was dependent on the weight change of the specimen. Once the weight change ratio was less than $0.0002 \% / \mathrm{min}$, the RH changed to the next humidity step. Three replications were performed for normal and compression wood.

\section{Statistical analysis}

The statistical software, SPSS version 17.0 (SPSS Inc, Chicago, IL, USA), was used for data analysis. Significant effects of sampling location on shrinking/swelling ratios were analyzed by Duncan's multiple comparison test $(p=0.05)$.

\section{Results and discussion}

It is widely accepted that the swelling properties of wood depend both on density and on the cellulose microfibril angle. In the following, firstly the microstructure of the investigated sample and the corresponding MFAs is described, followed by a detailed analysis and discussion of the swelling and sorption experiments.

\section{Microstructure and cellulose microfibril angle}

Naturally, cell wall proportions increased from early- to latewood. In normal earlywood, the cell wall ratio was as low as $10.6 \%$ and increased to $56.5 \%$ in latewood. Compression wood, which is known for its larger density (Timell 1986), showed smaller differences between early- and latewood with a cell wall proportion of $24.8 \%$ in early- and $44.2 \%$ in latewood. The ESEM micrographs furthermore show numerous intercellular spaces (Fig. 1 and 4d) and hint that the S3 is at least partly missing in the compression wood samples (Fig. 1 and 4). Light micrographs showing the helical cavities (Fig. 4b and 4e) confirm this finding. The helical cavities 


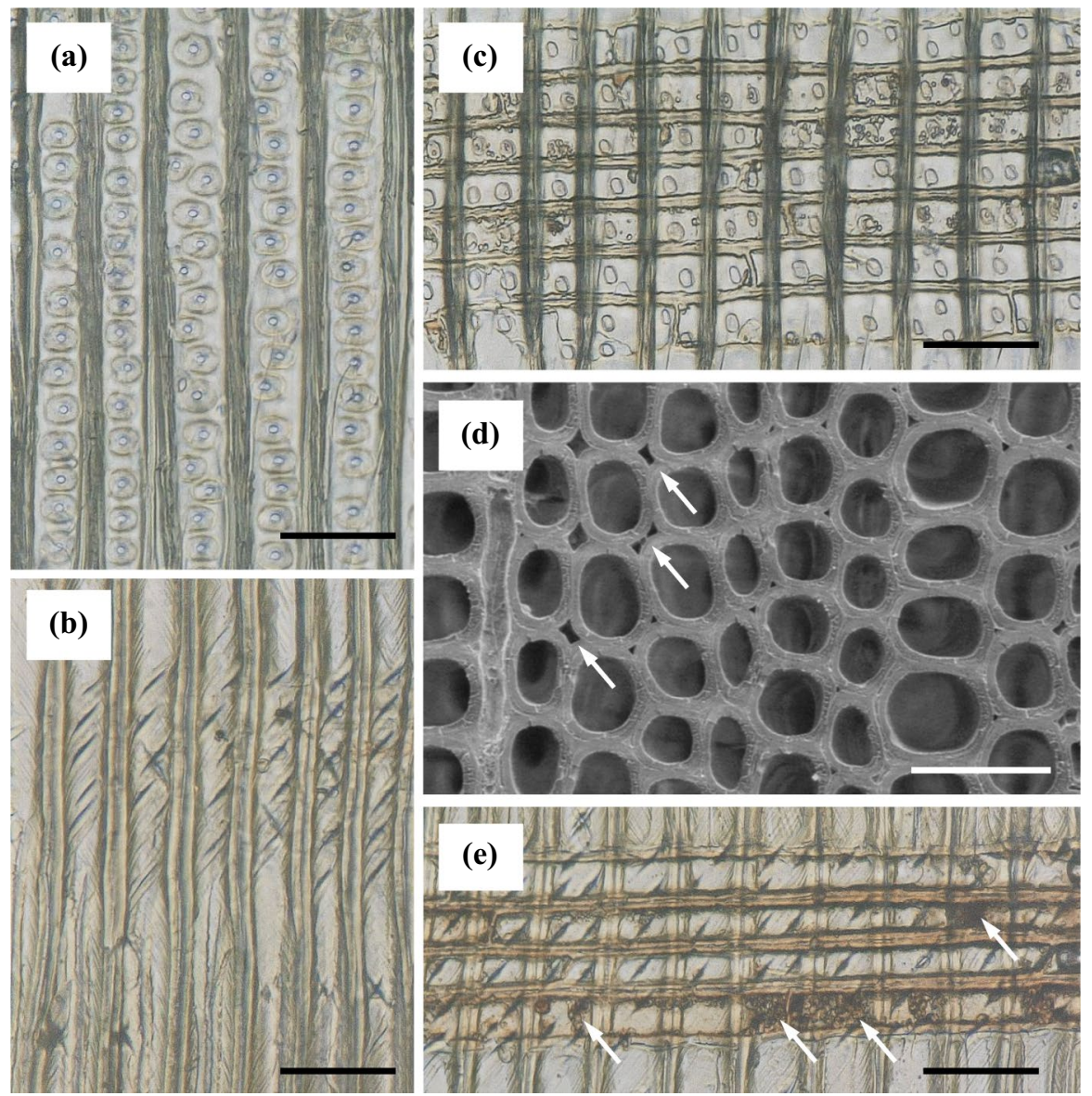

Fig. 4 Anatomical features of Chinese fir normal (a, c) and compression woods (b, $\mathbf{d}$ and $\mathbf{e})$. Bordered pits in normal wood (a), a number of helical cavities on tracheid walls of compression wood (b). Intercellular spaces (arrows) in cell corners of compression wood (d). Checks of cross-field pits in compression wood (e), no checks in normal wood (c). More orange cells (probably tannin-rich) in compression wood as arrows pointed in compression wood (e) than in normal wood (c). Scale bars in all Figs. $50 \mu \mathrm{m}$

together with checks point toward a high MFA (Barnett and Bonham 2004), which has been confirmed by the analysis of wide-angle X-ray diffraction data showing a MFA of $\sim 40^{\circ}$ for compression wood and a MFA of $\sim 11^{\circ}$ for normal wood. Compared with normal wood, compression wood possessed more tracheids and ray cells filled with an orange substance (Fig. 4e) which we assume are tannins due to their similar coloring as found in other tannin cells (Angyalossy et al. 2016).

\section{Area change of single cells}

Figure 5 shows the change in cross-sectional area change of single cells during desorption and absorption. It needs to be mentioned here that the low pressure inside 


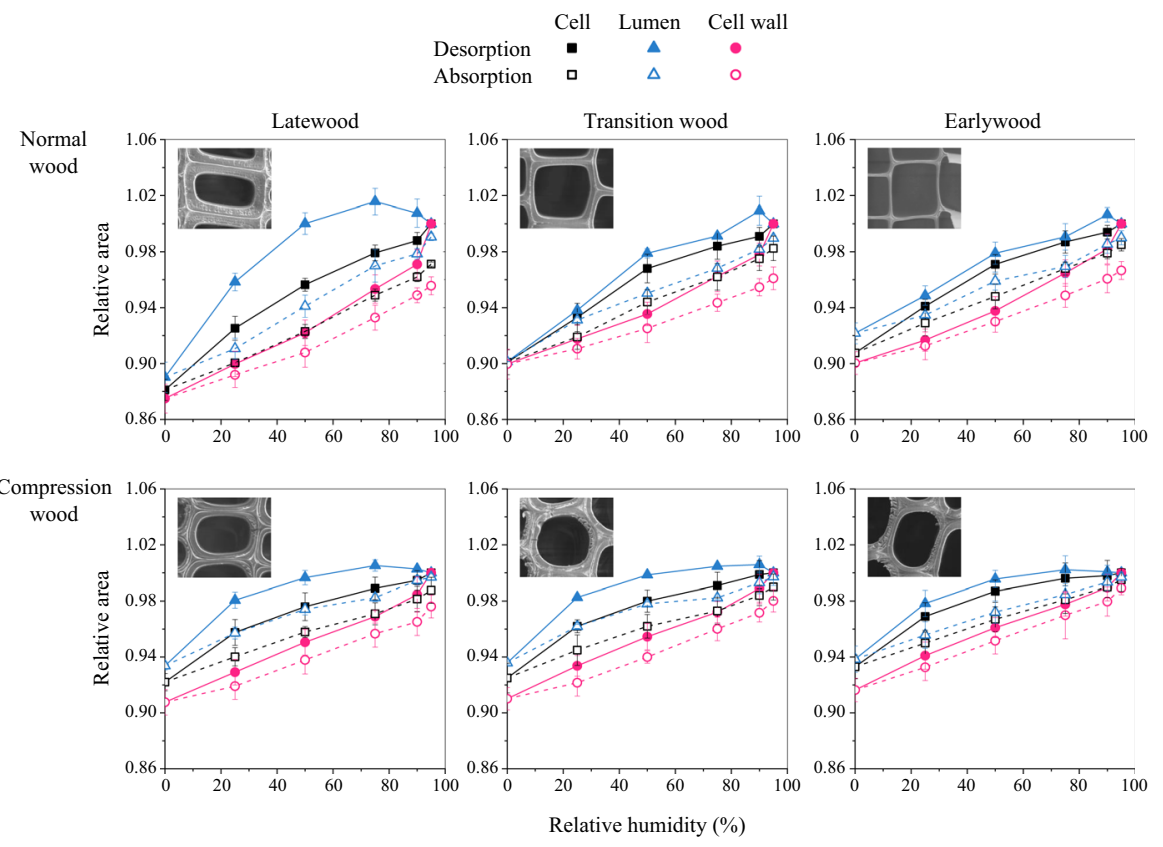

Fig. 5 Relative area of single cell during desorption and absorption as a function of humidity

the ESEM might affect area changes compared to experiments performed under ambient pressure conditions. However, a comparison with literature data is difficult since differences in structure have an immediate effect on swelling and shrinkage (Quirk 1984). Despite this uncertainty, comparisons between the studied tissue types are feasible and it is expected that observed trends are also valid under ambient conditions. The total area of the cells shrank as RH decreased and swelled as RH increased. When RH changes, water molecules are desorbed from or adsorbed onto the cell wall surface. Due to its large proportion in the cell wall, the S2 layer has the largest influence on the shrinkage and swelling behavior of wood (Siau 2012). Expectedly, the area changes of cell walls and cells showed similar patterns. The total area change of a cell is the combined change of cell wall and lumen. During the absorption process, the lumen, cell and cell wall swelled with increasing RH. Surprisingly, the lumens of all cell types initially expanded upon drying when RH decreased from 95 to $90 \%$ or even to $75 \%$ before they started to shrink. Normal latewood showed the most obvious lumen expansion, which reached as much as $1.57 \%$. The observed lumen expansions seem not to be a unique behavior of Chinese fir. Dimensional changes of lumens upon swelling have been a matter of debate already in 1933. Beiser (1933) found that lumens of both early- and latewood expanded upon swelling and discussed in his paper that this was in contrast to the findings of Mörath (1932), who was reported to suggest that lumen sizes decrease upon swelling. This result agrees well with the present observations that lumen areas increase during absorption. At that time, changes of lumen areas upon drying were not studied and in 1942 Stamm and Loughborough suggested that lumen sizes 
stay constant during moisture changes (Stamm and Loughborough 1942). Later, Quirk (1984) observed expansion of Douglas fir earlywood lumen, while latewood lumens reduced their size upon drying. More recent experiments showed increasing lumen sizes upon drying for Caribbean pine (Ma and Rudolph 2006) and the opposite behavior in Douglas fir early- and latewood (Murata and Masuda 2006). These different findings highlight that it is not surprising to read in recent reviews that dimensional changes of lumens are still a topic of controversy (Arzola-Villegas et al. 2019). What the present results now clearly show are differences in lumen expansion and shrinkage during absorption and desorption, with consistent trends but varying magnitudes. During the initial phase of the desorption process, the inner side (lumen side) of the cell shrinks more easily than the outer cell wall, because the lignified middle lamella is assumed to donate resistance to lateral movement of cell wall (Quirk 1984). Furthermore, it is speculated that drying-induced increase in cell wall stiffness might play an additional role. The size changes of cells are possibly a trade-off of the stretch and restrain among cell wall and lumen, also among different layers in the secondary wall, and the lumen expansion of Chinese fir may contribute to the reduction of the drying stress.

Among the different cell types (normal or compression wood, latewood, transition wood or earlywood), their area changes showed similar trends but different values which depended particularly on the cell wall thickness. For both normal and compression wood, the shrinking (from 95 to $0 \% \mathrm{RH}$ ) and swelling (from 0 to $95 \%$ $\mathrm{RH})$ ratios of cells decreased from latewood to transition wood and earlywood, due to decreasing cell wall proportions. Regardless of the sampling location, the area changes of cell walls were always larger than those of cells in both desorption and absorption processes. In the RH range from 50 to $90 \%$, the area changes of cell and cell wall behaved quasi-linear in both desorption and absorption processes, which was also reported in a previous study (Murata and Masuda 2006).

\section{Area changes at the tissue, cell and cell wall levels}

In Fig. 6, the relative areas of normal and compression latewood are shown and were compared among tissue, cell and cell wall levels. During the desorption process, the relative area change of tissue is between cell and cell wall for all $\mathrm{RH}$ condition. At $0 \% \mathrm{RH}, R A$ was $0.876,0.881$ and 0.875 for tissue, cell and cell wall level in normal latewood and $0.915,0.922$ and 0.908 for tissue, cell and cell wall level in compression latewood. These results reflect the interdependencies between cell wall, cell and tissue. Wood is a sophisticated system, which has the abilities to fine-tune its structure at various scales (Fratzl and Weinkamer 2007). At the cell level, a cell can be seen as the compound of cell wall and lumen and its size change is the sum of lumen and multi-layered cell wall changes. Although the role of the lumen as a hollow space is often restricted to densityrelated aspects, the relative humidity in this empty space is directly connected to cell wall swelling and shrinkage as the observed dimensional changes show. Of course, only the cross section of a bulk sample could be investigated, but due to the 12-h long equilibration times it is assumed that lumens of closed cells would 


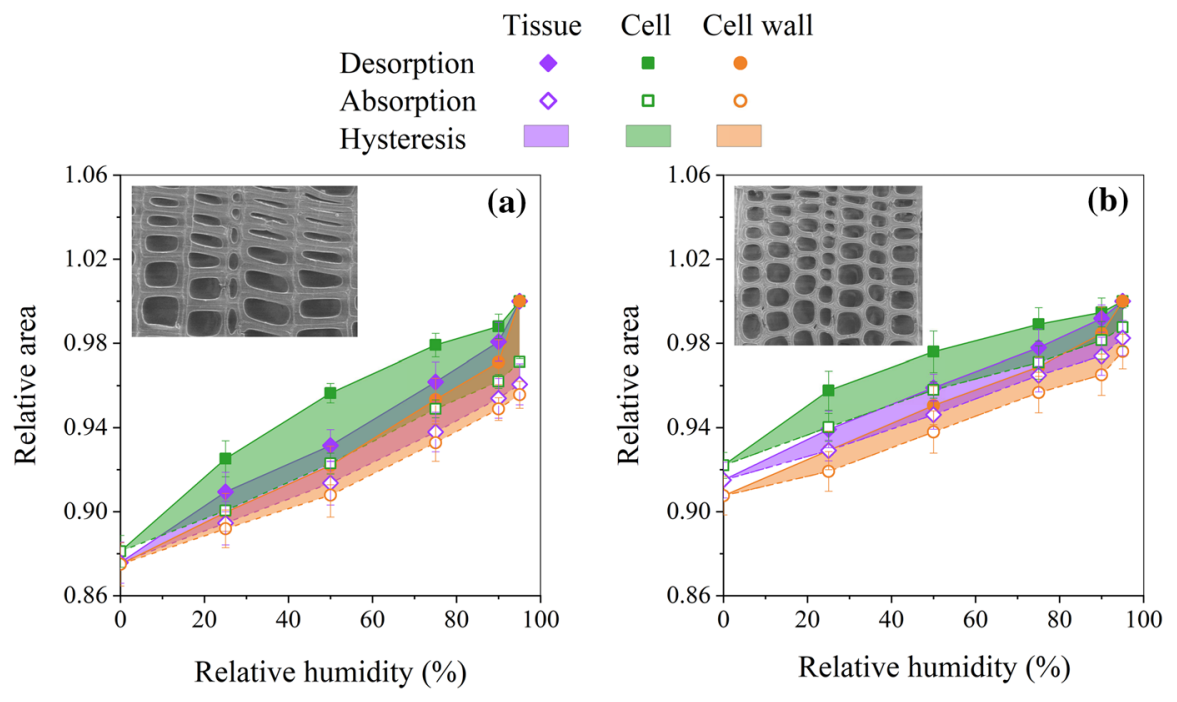

Fig. 6 Relative areas of normal (a) and compression (b) latewood at three levels: tissue, cell and cell wall

have also reached the same relative humidity. At the tissue level, the tracheids are attached to each other by middle lamella. As the MC changes, the middle lamellae are the connection that allows simultaneous deformation of adjacent cells (at least in small samples or sample areas). However, middle lamellae also contribute to the shrinking or swelling, and according to Nečesaný (1966), the hygroscopic deformations of highly lignified middle lamellae are larger than those of cells. This could explain why dimensional changes at the tissue level are larger than on the cell level.

Figure 6 shows that the area change in compression wood was less than in normal wood at all the three levels. This is not surprising and can be explained by the higher MFA ( $40^{\circ}$ in compression wood vs. $10^{\circ}$ in earlywood) which causes reduced swelling and shrinkage in the transverse direction and increased swelling in the longitudinal direction (Burgert et al. 2007). When comparing $R A$ of the desorption and the subsequent absorption, differences at the same RH condition have been observed. This swelling hysteresis is indicated by shaded areas in Fig. 6. The swelling hysteresis is associated with the sorption hysteresis, which will be described in detail in the section Swelling hysteresis.

A comparison of early- and latewood swelling is shown in Fig. 7. The trend that $R A_{\text {cell }}$ changes less upon humidity changes than $R A_{\text {tissue }}$ and $R A_{\text {cell wall }}$ was observed for both desorption and absorption processes. During the desorption process, the difference between $R A_{\text {cell }}$ and $R A_{\text {tissue }}$ was larger than that during absorption, especially at 25,50 or $75 \% \mathrm{RH}$. When $\mathrm{RH}$ was $50 \%$, the value " $R A_{\text {cell }}-R A_{\text {tissue }}$ " was 0.025 and 0.010 , respectively, in desorption and absorption of the normal latewood. Besides, $R A$ changes at high humidity changes are more pronounced during desorption than absorption. It is speculated that this is caused by a simultaneous increase in cell wall and lumen area during absorption, while the initial phase of the desorption process 


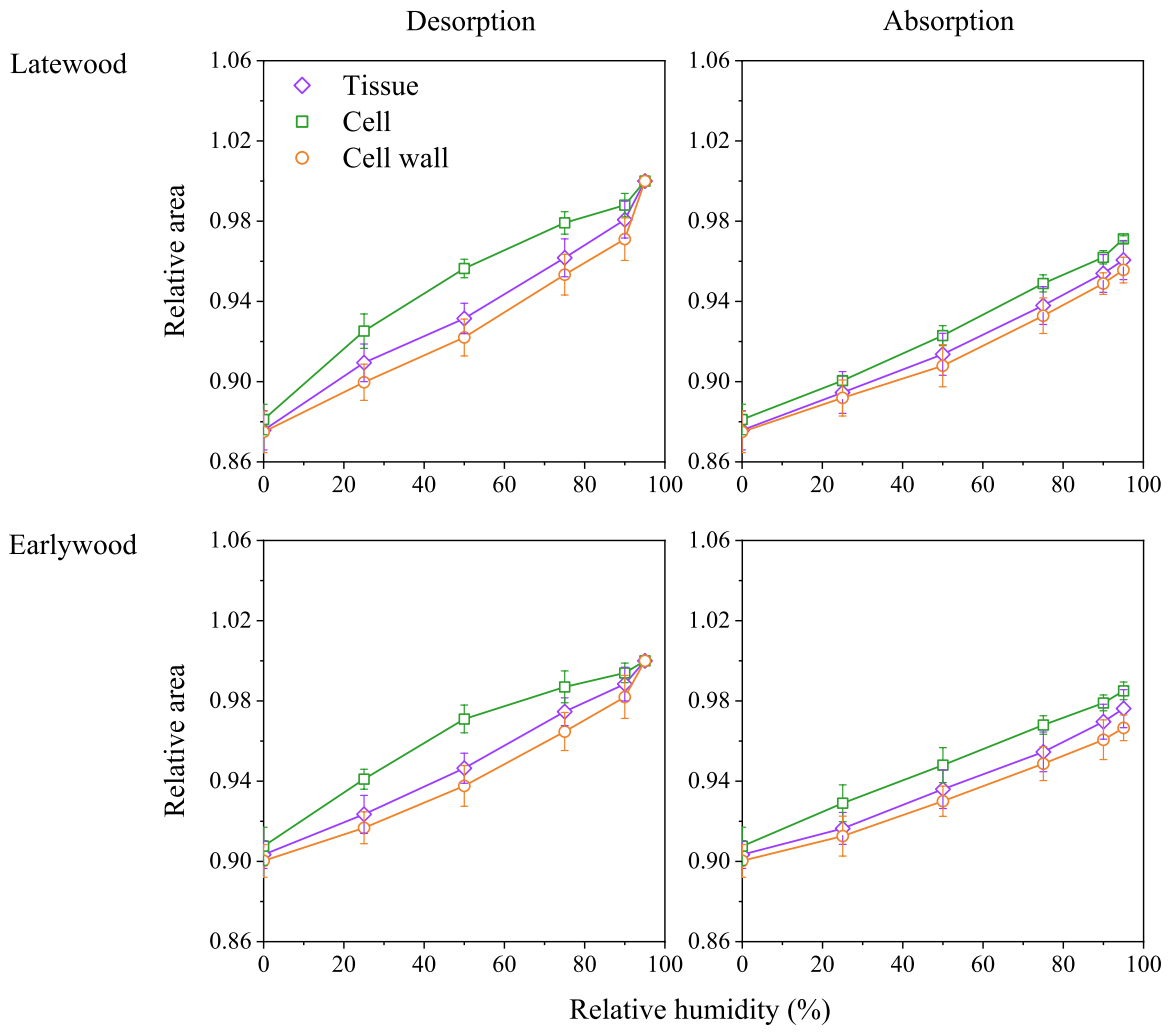

Fig. 7 Relative areas of normal latewood and earlywood during desorption or absorption process

is characterized by a lumen expansion and a more pronounced cell wall shrinkage (Fig. 5).

Naturally, the area changes of the earlywood tissue, cell or cell wall were less than in latewood (Fig. 7), due to the smaller cell wall proportion. For the tissue level, both shrinking $(95 \rightarrow 0 \% \mathrm{RH})$ and swelling $(0 \rightarrow 95 \% \mathrm{RH})$ ratios of earlywood were more than $10 \%$ smaller than in latewood. In addition, the swelling hysteresis was also smaller.

\section{Roles of MFA and cell wall ratio in dimensional changes}

During growth, trees manifest a wide variability of adaptable parameters of cell wall organization (MFA, cell size and cell wall proportion) to optimize water transport and mechanical support (Burgert et al. 2007; Eder et al. 2008; Reiterer et al. 2001). These adaptable parameters affect the shrinking/swelling and mechanical properties of wood. To explain the roles of MFA and cell wall ratio, the dimensional changes (shrinking and swelling ratios) are presented as a function of MFA and cell wall ratio, respectively, in Fig. 8 and 9. In Fig. 8, it is obvious that the shrinking ratio 

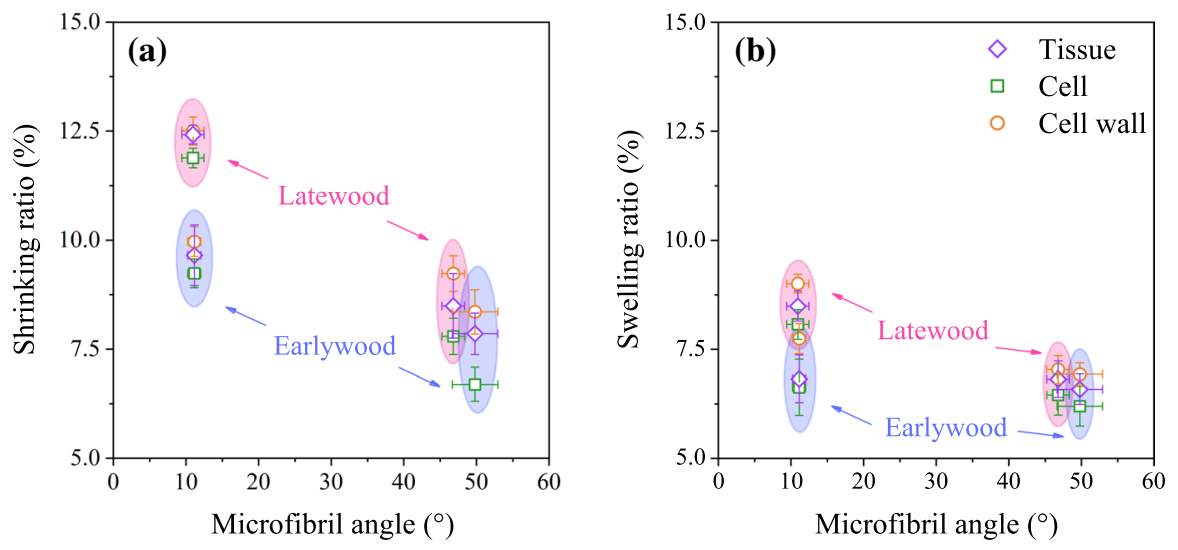

Fig. 8 Relationship of microfibril angle and shrinking $(95 \rightarrow 0 \% \mathrm{RH})$ or swelling $(0 \rightarrow 95 \% \mathrm{RH})$ ratio at tissue, cell and cell wall levels
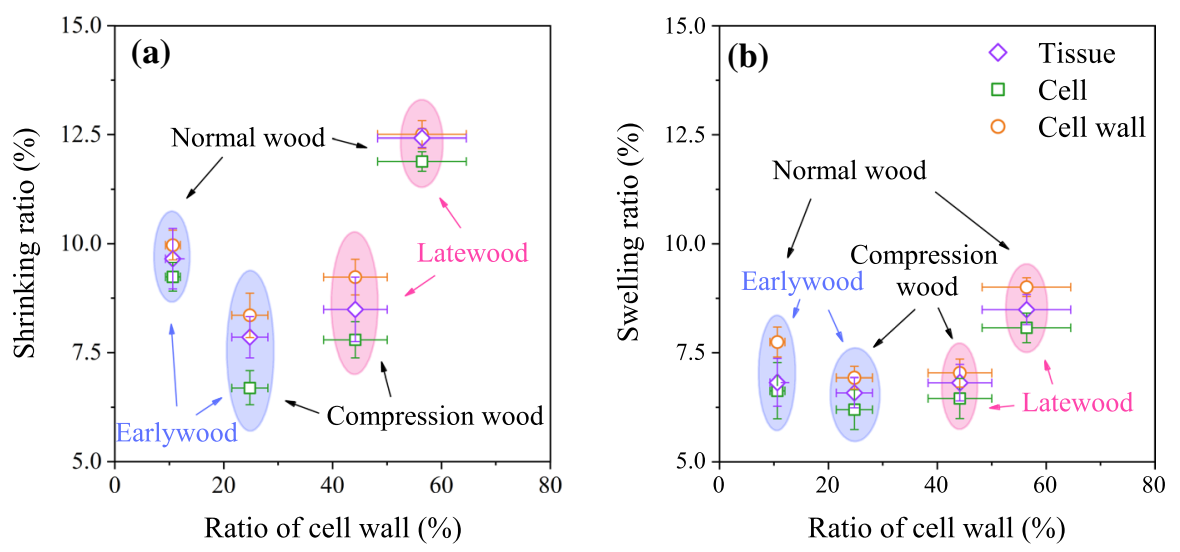

Fig. 9 Relationship of cell wall ratio and shrinking $(95 \rightarrow 0 \% \mathrm{RH})$ or swelling $(0 \rightarrow 95 \% \mathrm{RH})$ ratio at tissue, cell and cell wall levels

of normal latewood is higher than normal earlywood, which can be related to the higher cell wall proportion in the cross section. The significantly higher MFA of compression wood is clearly reflected in smaller dimensional changes of the cell wall. Due to the observed swelling hysteresis (Fig. 6), swelling ratios were less obvious than shrinking ratios for all samples (Fig. 8).

While significant differences in tissue swelling and shrinkage have been found between normal early- and latewood $(p<0.05)$, no statistically significant differences existed between early- and latewood of compression wood. The reason for this is twofold: (i) The higher MFA of compression wood leads to smaller area changes, and the differences in cell wall ratios of early- and latewood are smaller than in normal wood. Additionally, anatomical features of compression wood could play a role. This could include the presence of helical cavities in the tracheid walls (Fig. 4b and 
4e) absent in normal wood (Fig. 4a and 4c). In addition, voids existed in corners among almost round cross-sectional structure of tracheid (Fig. 4d).

\section{Swelling hysteresis}

Equilibrium MCs of normal and compression wood are shown in Fig. 10a. Independent of whether the equilibrium moisture content is measured in absorption or desorption, $\mathrm{MC}$ of the compression wood at a given humidity level was higher than the normal wood. The higher MC of the compression wood may be related to the greater deposition of hemicelluloses and lignin between microfibrils (Peng et al. 2019b; Plomion et al. 2001) and more tannin in tracheids (Fig. 4e). In this study, the sorption hysteresis was determined by the desorption isothermal (initiated from the water-saturated condition), and its value increased with increasing MC, which was different from the previous studies by using the scanning isothermal (Fredriksson and Thybring 2018; Hill et al. 2010; Xie et al. 2011). At given RHs (25, 50 and $75 \%$ ), sorption hysteresis of the compression wood was higher than the normal wood.

Based on results of MC (Fig. 10a) and area change at the cell wall level (Fig. 6), the relations are displayed in Fig. 10b. For both normal and compression wood, the relation was linear below a MC of $15 \%$. Similar findings were reported in previous studies (Ma and Rudolph 2006; Murata and Masuda 2006). Moreover, changes in relative area during desorption and subsequent absorption coincided at low MC ranges (less than 10\%), because adsorbed water molecule connected with cell wall surface directly. With further increasing MC, "mobile water" in small voids of the cell wall (Zelinka et al. 2012) had less impact on shrinking/swelling of cell wall polymers (swelling hysteresis in Fig. 10b). The relation between "sorption hysteresis" and "swelling hysteresis" was further constructed (Fig. 10c). These two hystereses were positively correlated. As a function of sorption hysteresis, swelling hysteresis of normal wood was significantly higher than compression wood (Fig. 10c). This result points to an interesting interrelation between sorption and swelling hysteresis. The sorption hysteresis is considered to be related to the mechanics of shrinkage and swelling of the cell walls during changes in MC (Engelund et al. 2013; Hill et al. 2012). Commonly, more lignin content would cause more hysteresis in wood cell
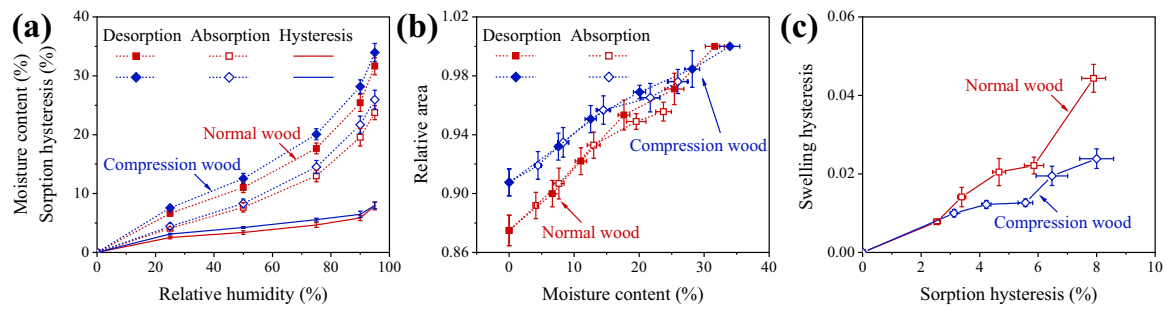

Fig. 10 a Moisture content and sorption hysteresis of normal and compression wood as a function of relative humidity. b Relative areas of normal and compression latewood at cell wall level during desorption and absorption processes. c Relations of swelling hysteresis and sorption hysteresis of normal and compression latewood at cell wall level 
wall (Derome et al. 2018; Kulasinski et al. 2015b). Compression wood of Chinese fir has more lignin content than normal wood (Peng et al. 2019b), which is consistent with the sorption hysteresis magnitude observed in Fig. 10a and b.

Due to higher MFA values, values of shrinking and swelling of compression wood were lower compared to normal wood, which at least partially explain the smaller swelling hysteresis. In addition, the absorption or desorption process results in the expansion or contraction of microcapillaries in the viscoelastic wood cell wall. The helical cavities in compression wood give rise to free movements of the $S 2$ layer to some extent and also influence the size changes of microcapillaries. It should be pointed out here that the in situ shrinking and swelling tests and the desorption isothermal tests were carried out at 6 and $25{ }^{\circ} \mathrm{C}$, respectively. These temperature differences as well as the above-mentioned differences in pressure were not considered in the interpretation, and it cannot be excluded that additional effects arise from them. We also need to consider that the swelling hysteresis was evaluated only in the transverse 2D-plane, and the dimensional changes in the longitudinal direction were not considered, while the sorption experiments were performed on the whole 3D wood material. Burgert et al. (2007) revealed that normal and compression wood showed contrary dimensional change in the longitudinal direction. Hence, a comprehensive consideration of the swelling hysteresis, especially for compression wood, should also consider the deformation in both transverse and longitudinal directions. Nevertheless, the results presented allow the comparison of compression and normal wood swelling in the 2D transverse direction and the sorption hysteresis for the same material.

\section{Conclusion}

In this paper, shrinking and swelling of Chinese fir wood was studied at the tissue, cell and cell wall level by in situ-ESEM experiments to explore variations between normal and compression wood. The findings contribute to a more holistic understanding of how wood responds to moisture changes from the cell wall to the tissue level in the transverse direction.

During initial desorption from 95 to 90 or $75 \%$ RH, the size of lumens increased. The different dimensional changes of cell walls and lumens illustrate a non-uniform and directional shrinking/swelling process and suggest that lumens could contribute to a reduction in drying stresses acting on the middle lamella. However, this needs further investigations and should be complemented by numerical or analytical methods. A comparison of the swelling/shrinkage behavior at the different length scales revealed that the response of tissues to changes in humidity was between cell and cell wall response, which suggests that middle lamellae swelling/shrinkage is not negligible. Observed lower dimensional changes of compression wood in the transverse direction were related to the integrated effects of the structure, i.e., a higher MFA, smaller differences in early- and latewood density as well as anatomical characteristics such as helical cavities and intercellular spaces between the cells. This newly generated dataset contributes to a deeper understanding of the relationships 
between wood structure and swelling/shrinkage properties in at least 2 dimensions and provides a basis for a more targeted material use.

Acknowledgements We wish to thank Susann Weichold, Friedrich Reppe and Nils Horbelt for their technical supports and John WC Dunlop for linguistic revisions.

Funding Open Access funding enabled and organized by Projekt DEAL. This work was financially supported by the National Key Research and Development Program of China (2017YFD0600202), the National Natural Science Foundation of China (No. 31971591, 31700487) and the Advanced Analysis and Testing Center of Nanjing Forestry University. T.Z. would like to gratefully acknowledge the financial support from the Jiangsu Provincial Government Scholarship Program. M.E. acknowledges the support of the Cluster of Excellence "Matters of Activity. Image Space Material" funded by the Deutsche Forschungsgemeinschaft (DFG, German Research Foundation) under Germany's Excellence StrategyEXC 2025-390648296 and the support of the Max Planck Society.

\section{Declarations}

Conflict of interest The authors declare that they have no conflict of interest.

Open Access This article is licensed under a Creative Commons Attribution 4.0 International License, which permits use, sharing, adaptation, distribution and reproduction in any medium or format, as long as you give appropriate credit to the original author(s) and the source, provide a link to the Creative Commons licence, and indicate if changes were made. The images or other third party material in this article are included in the article's Creative Commons licence, unless indicated otherwise in a credit line to the material. If material is not included in the article's Creative Commons licence and your intended use is not permitted by statutory regulation or exceeds the permitted use, you will need to obtain permission directly from the copyright holder. To view a copy of this licence, visit http://creativecommons.org/licen ses/by/4.0/.

\section{References}

Abe K, Yamamoto H (2005) Mechanical interaction between cellulose microfibril and matrix substance in wood cell wall determined by X-ray diffraction. J Wood Sci 51:334-338. https://doi.org/10.1007/ s10086-004-0667-6

Abe K, Yamamoto H (2006) Change in mechanical interaction between cellulose microfibril and matrix substance in wood cell wall induced by hygrothermal treatment. J Wood Sci 52:107-110. https://doi. org/10.1007/s10086-005-0738-3

Angyalossy V, Pace MR, Evert RF et al (2016) IAWA list of microscopic bark features. IAWA J 37:517-615

Arzola-Villegas X, Lakes R, Plaza NZ, Jakes JE (2019) Wood moisture-induced swelling at the cellular scale—ab intra. Forests 10:996. https://doi.org/10.3390/f10110996

Bao FC, Jiang ZH, Jiang XM, Lu XX, Luo XQ, Zhang SY (2001) Differences in wood properties between juvenile wood and mature wood in 10 species grown in China. Wood Sci Technol 35:363-375. https://doi.org/10.1007/s002260100099

Barnett JR, Bonham VA (2004) Cellulose microfibril angle in the cell wall of wood fibres. Biol Rev 79:461-472. https://doi.org/10.1017/S1464793103006377

Beiser W (1933) Mikrophotographische Quellungsuntersuchungen von Fichten- und Buchenholz an Mikrotomschnitten im durchfallenden Licht und an Holzklötzchen im auffallenden Licht (Microphotographic swelling investigations of spruce and beech wood on microtome sections in transmitted light and on wood blocks in incident light) (In German). Kolloid-Zeitschrift 65:203-211. https://doi.org/ 10.1007/BF01520570 
Burgert I, Frühmann K, Keckes J, Fratzl P, Stanzl-Tschegg S (2005) Properties of chemically and mechanically isolated fibres of spruce (Picea abies[L.] Karst.) Part 2: twisting phenomena. Holzforschung 59:247. https://doi.org/10.1515/HF.2005.039

Burgert I, Eder M, Gierlinger N, Fratzl P (2007) Tensile and compressive stresses in tracheids are induced by swelling based on geometrical constraints of the wood cell. Planta 226:981-987. https://doi.org/ 10.1007/s00425-007-0544-9

Chen M, Coasne B, Guyer R, Derome D, Carmeliet J (2018) Role of hydrogen bonding in hysteresis observed in sorption-induced swelling of soft nanoporous polymers. Nat Commun 9:3507. https:// doi.org/10.1038/s41467-018-05897-9

Chen Q, Fang C, Wang G et al (2020) Hygroscopic swelling of moso bamboo cells. Cellulose 27:611620. https://doi.org/10.1007/s10570-019-02833-y

Derome D, Griffa M, Koebel M, Carmeliet J (2011) Hysteretic swelling of wood at cellular scale probed by phase-contrast X-ray tomography. J Struct Biol 173:180-190. https://doi.org/10.1016/j.jsb.2010. 08.011

Derome D, Kulasinski K, Zhang C, Chen M, Carmeliet J (2018) Using modeling to understand the hygromechanical and hysteretic behavior of the S2 cell wall layer of wood. In: Geitmann A, Gril J (eds) Plant biomechanics: from structure to function at multiple scales. Springer International Publishing, Cham, pp 247-269

Eder M, Jungnikl K, Burgert I (2008) A close-up view of wood structure and properties across a growth ring of Norway spruce (Picea abies [L] Karst.). Trees 23:79-84. https://doi.org/10.1007/ s00468-008-0256-1

Eder M, Schäffner W, Burgert I, Fratzl P (2020) Wood and the activity of dead tissue. Adv Mater 33:2001412. https://doi.org/10.1002/adma.202001412

Engelund ET, Thygesen LG, Svensson S, Hill CA (2013) A critical discussion of the physics of wood-water interactions. Wood Sci Technol 47:141-161

Fratzl P, Weinkamer R (2007) Nature's hierarchical materials. Prog Mater Sci 52:1263-1334. https:// doi.org/10.1016/j.pmatsci.2007.06.001

Fredriksson M, Thybring EE (2018) Scanning or desorption isotherms? Characterising sorption hysteresis of wood. Cellulose 25:4477-4485. https://doi.org/10.1007/s10570-018-1898-9

Garcia RA, Rosero-Alvarado J, Hernández RE (2020) Full-field moisture-induced strains of the different tissues of tamarack and red oak woods assessed by $3 \mathrm{D}$ digital image correlation. Wood Sci Technol 54:139-159. https://doi.org/10.1007/s00226-019-01145-5

Grönquist P, Wood D, Hassani MM, Wittel FK, Menges A, Rüggeberg M (2019) Analysis of hygroscopic self-shaping wood at large scale for curved mass timber structures. Sci Adv 5:eaax1311. https://doi.org/10.1126/sciadv.aax 1311

Hill CAS, Norton AJ, Newman G (2010) The water vapour sorption properties of Sitka spruce determined using a dynamic vapour sorption apparatus. Wood Sci Technol 44:497-514. https://doi. org/10.1007/s00226-010-0305-y

Hill CAS, Ramsay J, Keating B, Laine K, Rautkari L, Hughes M, Constant B (2012) The water vapour sorption properties of thermally modified and densified wood. J Mater Sci 47:3191-3197. https:// doi.org/10.1007/s10853-011-6154-8

Jiang J, Lu J, Ren H, Long C (2012) Effect of growth ring width, pith and visual grade on bending properties of Chinese fir plantation dimension lumber. Eur J Wood Prod 70:119-123. https://doi. org/10.1007/s00107-011-0529-z

Joffre T, Neagu RC, Bardage SL, Gamstedt EK (2014) Modelling of the hygroelastic behaviour of normal and compression wood tracheids. J Struct Biol 185:89-98. https://doi.org/10.1016/j.jsb. 2013.10.014

Joffre T, Isaksson P, Dumont PJ, Du Roscoat SR, Sticko S, Orgéas L, Gamstedt EK (2016) A method to measure moisture induced swelling properties of a single wood cell. Exp Mech 56:723-733. https://doi.org/10.1007/s11340-015-0119-9

Keey R, Langrish T, Walker J (2000) Kild-drying of lumber. Springer-Verlag, Berlin, Heidelberg, New York

Kulasinski K, Guyer R, Derome D, Carmeliet J (2015) Poroelastic model for adsorption-induced deformation of biopolymers obtained from molecular simulations. Phys Rev E 92:022605. https://doi.org/10.1103/PhysRevE.92.022605

Kulasinski K, Guyer R, Derome D, Carmeliet J (2015) Water adsorption in wood microfibril-hemicellulose system: Role of the crystalline-amorphous interface. Biomacromolecules 16:2972-2978 
Lanvermann C, Wittel FK, Niemz P (2014) Full-field moisture induced deformation in Norway spruce: intra-ring variation of transverse swelling. Eur J Wood Prod 72:43-52. https://doi.org/10. 1007/s00107-013-0746-8

Lichtenegger H, Reiterer A, Tschegg S, Fratzl P (1997) Determination of spiral angles of elementary fibrils in the wood cell wall: comparison of small-angle X-ray scattering and wide-angle X-ray diffraction. Microfibril Angle in Wood: the Proceedings of the IAWA/IUFRO International Workshop on the Significance of Microfibril Angle to Wood Quality, Westport, New Zealand 1997:140-156

Ma Q, Rudolph V (2006) Dimensional change behavior of caribbean pine using an environmental scanning electron microscope. Dry Technol 24:1397-1403. https://doi.org/10.1080/07373930600952743

Ma E, Nakao T, Zhao G, Ohata H, Kawamura S (2010) Dynamic sorption and hygroexpansion of wood subjected to cyclic relative humidity changes. Wood Fiber Sci 42:229-236

Mörath E (1932) Studien über die hygroskopischen Eigenschaften und Härte der Hölzer, (Studies on the hygroscopic properties and hardness of wood) (In German). Issue 1 pp. 12 and 14, secondary source from Beiser 1933

Murata K, Masuda M (2006) Microscopic observation of transverse swelling of latewood tracheid: effect of macroscopic/mesoscopic structure. J Wood Sci 52:283-289. https://doi.org/10.1007/ s10086-005-0760-5

Nečesaný V (1966) Participation of cell wall and middle lamella in the shrinking and swelling of wood. Holz Roh- Werkst 24:470-473. https://doi.org/10.1007/bf02612877

Patera A, Derome D, Griffa M, Carmeliet J (2013) Hysteresis in swelling and in sorption of wood tissue. J Struct Biol 182:226-234. https://doi.org/10.1016/j.jsb.2013.03.003

Patera A, Van den Bulcke J, Boone MN, Derome D, Carmeliet J (2018) Swelling interactions of earlywood and latewood across a growth ring: global and local deformations. Wood Sci Technol 52:91114. https://doi.org/10.1007/s00226-017-0960-3

Peng H, Jiang JL, Lu JX, Cao JZ (2019a) Orthotropic mechano-sorptive creep behavior of Chinese fir during moisture desorption process determined in tensile mode. Wood Sci Technol 53:747-764. https://doi.org/10.1007/s00226-019-01104-0

Peng H, Salmen L, Stevanic JS, Lu J (2019b) Structural organization of the cell wall polymers in compression wood as revealed by FTIR microspectroscopy. Planta 250:163-171. https://doi.org/10. 1007/s00425-019-03158-7

Perré P (2005) Meshpore: a software able to apply image-based meshing techniques to anisotropic and heterogeneous porous media. Dry Technol 23:1993-2006. https://doi.org/10.1080/0737393050 0210432

Perré P, Huber F (2007) Measurement of free shrinkage at the tissue level using an optical microscope with an immersion objective: results obtained for Douglas fir (Pseudotsuga menziesii) and spruce (Picea abies). Ann For Sci 64:255-265. https://doi.org/10.1051/forest:2007003

Plaza N, Zelinka SL, Stone DS, Jakes JE (2013) Plant-based torsional actuator with memory. Smart Mater Struct 22:072001

Plomion C, Leprovost G, Stokes A (2001) Wood formation in trees. Plant Physiol 127:1513-1523. https:// doi.org/10.1104/pp.010816

Quirk JT (1984) Shrinkage and related properties of douglas-fir cell walls. Wood Fiber Sci 16:115-133

Rafsanjani A, Derome D, Guyer RA, Carmeliet J (2013) Swelling of cellular solids: from conventional to re-entrant honeycombs. Appl Phys Lett 102:211907. https://doi.org/10.1063/1.4807844

Rafsanjani A, Stiefel M, Jefimovs K, Mokso R, Derome D, Carmeliet J (2014) Hygroscopic swelling and shrinkage of latewood cell wall micropillars reveal ultrastructural anisotropy. J R Soc Interface 11:20140126

Redman AL, Bailleres H, Turner I, Perré P (2016) Characterisation of wood-water relationships and transverse anatomy and their relationship to drying degrade. Wood Sci Technol 50:739-757. https:// doi.org/10.1007/s00226-016-0818-0

Reiterer A, Lichtenegger H, Fratzl P, Stanzl-Tschegg SE (2001) Deformation and energy absorption of wood cell walls with different nanostructure under tensile loading. J Mater Sci 36:4681-4686. https://doi.org/10.1023/A:1017906400924

Sakagami H, Matsumura J, Oda K (2007) Shrinkage of tracheid cells with desorption visualized by confocal laser scanning microscopy. IAWA J 28:29-37

Siau JF (2012) Transport processes in wood, vol 2. Springer, Cham

Skaar C (2012) Wood-water relations. Springer, Cham 
Stamm AJ, Loughborough WK (1942) Variation in shrinking and swelling of wood. Trans Am Soc Mech Eng 64:379-386

Timell T (1986) Compression wood in gymnosperms. Springer, Berlin

Wang ML, Rennolls K (2005) Tree diameter distribution modelling: introducing the logit-logistic. Can J For Res-Revue Canadienne De Recherche Forestiere 35:1305-1313. https://doi.org/10.1139/ $\mathrm{x} 05-057$

Wang SY, Wang YS, Tseng YH, Lin CT, Liu CP (2006) Analysis of fragrance compositions of precious coniferous woods grown in Taiwan. Holzforschung 60:528-532. https://doi.org/10.1515/hf.2006. 087

Wood D, Vailati C, Menges A, Rüggeberg M (2018) Hygroscopically actuated wood elements for weather responsive and self-forming building parts-facilitating upscaling and complex shape changes. Constr Build Mater 165:782-791. https://doi.org/10.1016/j.conbuildmat.2017.12.134

Xie Y, Hill CAS, Jalaludin Z, Curling SF, Anandjiwala RD, Norton AJ, Newman G (2011) The dynamic water vapour sorption behaviour of natural fibres and kinetic analysis using the parallel exponential kinetics model. J Mater Sci 46:479-489. https://doi.org/10.1007/s10853-010-4935-0

Yin YF, Nagao H, Liu XL, Nakai T (2010) Mechanical properties assessment of Cunninghamia lanceolata plantation wood with three acoustic-based nondestructive methods. J Wood Sci 56:33-40. https://doi.org/10.1007/s10086-009-1067-8

Yin JP, Song KL, Lu Y, Zhao GJ, Yin YF (2015) Comparison of changes in micropores and mesopores in the wood cell walls of sapwood and heartwood. Wood Sci Technol 49:987-1001. https://doi.org/10. 1007/s00226-015-0741-9

Zabler S, Paris O, Burgert I, Fratzl P (2010) Moisture changes in the plant cell wall force cellulose crystallites to deform. J Struct Biol 171:133-141. https://doi.org/10.1016/j.jsb.2010.04.013

Zelinka SL, Lambrecht MJ, Glass SV, Wiedenhoeft AC, Yelle DJ (2012) Examination of water phase transitions in Loblolly pine and cell wall components by differential scanning calorimetry. Thermochim Acta 533:39-45

Zhan T, Kuai B, Lyu C, Wang X, Xu K, Zhang Y (2019) Moisture dependence of the tensile strength perpendicular to grain of poplar and Chinese fir. J Forestry Eng 4:34-39

Publisher's Note Springer Nature remains neutral with regard to jurisdictional claims in published maps and institutional affiliations. 